\title{
Verifying Student Engagement and Learning Development in Higher Education by SES
}

\author{
Dian-fu Chang ${ }^{1}$, Wen-ching Chou ${ }^{2}$ and Shu-ching $\mathrm{Wu}^{2}$ \\ ${ }^{1}$ Graduate Institute of Educational Policy and Leadership, Tamkang University \\ No. 151, Yingzhuan Rd., Tamsui Dist., New Taipei City 25137, Taiwan \\ ${ }^{2}$ Department of Educational Policy and Administration, National Chi Nan University \\ No. 1, Daxue Rd., Puli Township, Nantou County 54561, Taiwan
}

\begin{abstract}
This study aims to explore the student engagement and learning development in higher education based on social economic status. The data were collected by using the student engagement questionnaire in Taiwan. There are 2,651 valid cases were analyzed in this study. Both t-test and one-way ANOVA were applied to interpret the data. The result reveals that the student engagement and learning development are in unsatisfied level; their participations are moderate; attitudes and approaches for learning are in middle level, and students' learning development is below the average level. Both low and high SES group are inferior in their engagement and learning development. The findings can be used to ameliorate this issue in the higher education system.
\end{abstract}

Index Terms - Higher education. Student engagement. Learning development. Social economic status (SES).

\section{Introduction}

During the last three decades, the capacity of Taiwan's higher education has expanded rapidly. In academic year 2013, there were 162 universities and colleges, including 120 universities, 28 independent colleges, and 14 junior colleges. The popularization of education has led to a rapid increase in student enrolment, although the figure has levelled off in the last decade. The number of students has increased from 358,000 in 1974 to $1,355,290$ in 2013, an almost four-fold expansion in the system [1]. According to 2012 Education Statistical Indicators, the tertiary education gross enrolment rate (GER) has reached 84\%, higher than in most other Asian countries [2]. The expanded higher education system also caused public concern about her quality. This study considered the student engagement and learning development issues in this system. Previous studies indicated that college students' time and energy devoted to purpose activities in campus has become one of useful predictors to explain their learning and personal development [3-6]. Various studies have addressed the issues from different viewpoints. However, the social economic status has little be considered in an expanded higher education system. Given this purpose, this study addressed the issue of student engagement and learning development issues in Taiwan.

\section{Conceptual Framework of Student Engagement}

Chickering and Gamson demonstrated that "Seven Principles for Good Practice in Undergraduate Education" has become well known engagement indicators. Their principles include student-faculty contact, cooperation among students, active learning, Feedback, time on task, high expectations, and respect for diverse talents [7]. Student engagement is defined as a concept that requires psychological connections within the academic environment (e.g., positive relationships between adults and peers) in addition to student's active behaviours (e.g., attendance and effort). Effective interventions have also addressed related to student engagement comprehensively. The focusing has found not only on academic or behavioural skills, but also on social and interpersonal activities, particularly the need for supportive connections to other adults and peers [8].

Student engagement is not conceptualized as an attribute of the student, but rather a state of being that is highly influenced by contextual factors, like home, school, and peers, that will provide consistent support for student learning [9]. Various studies agreed that student engagement is a relevant and multidimensional conception with well construction. It can be used to integrate students' thoughts, feelings, and behaviours [10-11]. Generally, previous studies have incorporated the concept into affective, behavioural, and cognitive engagement[10][12]. Our conceptual research framework of student engagement argued that students demonstrate their levels of engagement through a variety of behavioural, emotional, and cognitive engagement. Participation, in terms of behavioural engagement, includes basic behaviours such as amount of reading and writing, frequency of learning activities of campus life, which will explain by active effort, student-faculty interaction, and civic issues. Affective component of student engagement refers to the student's feelings of belonging in campus and valuing the outcomes that college provided, which will explain by student's interest, motivation, and concentration on courses. Approaches, in the cognitive dimension, have divided into four cognitive strategies, namely analysis, integration, judgment, and application as our conceptual framework in this dimension.

Highly engaged students show that their behavioural involvement in learning activities accompanied by positive emotions. They usually demonstrate positive emotions during ongoing actions including enthusiasm, optimism, curiosity, and interest [13]. Furlong and Christenson pointed that student engagement has practical implications [11]. To determine the relationships, this study focuses on the variables that might have high relationships with student engagement. 


\section{Research Design}

This study has followed the NSSE's questionnaire to collect students' view on their engagement [14]. The adapted questionnaire includes backgrounds, dimensions of student engagement, and learning development. The selected key variables in this study are listed as Table I.

TABLE I Key Variables of Questionnaire

\begin{tabular}{|c|c|}
\hline Variables & Questionnaire contents \\
\hline \multicolumn{2}{|l|}{ Backgrounds } \\
\hline student background & Gender, major field, grade, family SES \\
\hline university background & $\begin{array}{l}\text { Public/private, general/vocational, } \\
\text { location of universities }\end{array}$ \\
\hline \multicolumn{2}{|l|}{ Student engagement } \\
\hline participation & $\begin{array}{l}\text { Amount of reading and writing, frequency } \\
\text { of learning activities }\end{array}$ \\
\hline attitudes & Experiences or attitudes to courses \\
\hline approaches & Cognitive approaches \\
\hline \multicolumn{2}{|l|}{ Learning development } \\
\hline academic performance & GPA (score) \\
\hline learning satisfaction & Satisfaction of learning activities \\
\hline career development & $\begin{array}{l}\text { Career ambition (internships, study } \\
\text { abroad, community service, working on a } \\
\text { research project, preparing for exams) }\end{array}$ \\
\hline
\end{tabular}

The participants were asked to fill their responses in the 5-point Likert scale $(1=$ strongly disagree/never, $2=$ disagree/seldom, $3=$ no comments/sometimes, $4=$ agree/usually, $5=$ strongly agree/always). The original set of questions includes 53 items. After experts' reviewing and pilot testing, the items were revised and reduced to 40. In participation of reading and writing, Cronbach's $\alpha$ is .779 (with 59.114\% of variance explained). In participation frequency of learning activities, Cronbach's $\alpha$ is .914 (with $54.422 \%$ variance explained). In attitudes of experiences or attitudes to courses, Cronbach's $\alpha$ is .627 (with $49.720 \%$ of variance explained). In cognitive approaches, Cronbach's $\alpha$ is .796 (with $54.655 \%$ of variance explained). According to the Cronbach's $\alpha$ test, the reliability of our questionnaire is quite fit. The samples are 2,651 students from 13 universities or colleges. It represents the sampling at $95 \%$ confident level. T-test and one-way ANOVA were used to analyze the data.

\section{Results}

\section{A. Engaged in Reading and Writing}

TABLE II Amount of Reading and Writing per Academic Year by Students

\begin{tabular}{|l|c|c|c|c|c|}
\hline Reading/writing per academic year & None & $1-4$ & $5-10$ & $11-20$ & $\begin{array}{c}20 \text { or } \\
\text { more }\end{array}$ \\
\hline Amount of reading & & & & & \\
\hline 1. Number of assigned books & 3.7 & 31.9 & 48.4 & 11.9 & 4.1 \\
\hline 2. Number of non-assigned books & 8.5 & 40.2 & 31.6 & 12.4 & 7.0 \\
\hline Amount of writing & & & & & \\
\hline 1. Number of papers of 20 pages or more & 37.3 & 37.9 & 18.1 & 4.9 & 1.6 \\
\hline 2. Number of papers of 5-19 pages & 16.4 & 48.9 & 25.2 & 7.4 & 1.8 \\
\hline 3. Number of papers of 5 pages or less & 15.8 & 47.1 & 23.0 & 9.1 & 4.7 \\
\hline
\end{tabular}

Note. The number represents percent (\%).

Reviewing the number of assigned books to read per academic year, the result shows $84.0 \%$ of students reported they read fewer than 11, while the non-assigned books to read fewer than 11, there are $80.3 \%$ of students say yes. In the writing engagement, referring the number of papers written per academic year, there are $37.3 \%$ of students expressed "none" in the item of 20 pages or more, and $15.8 \%$ of students said "none" in the item of 5 pages or less. The details amount of reading and writing per academic year for the students have presented in Table II.

\section{B. Analysis of Student Engagement}

TABLE III Descriptive Statistics for Student Engagement

\begin{tabular}{|l|l|c|c|}
\hline Dimensions & Factors & Means & S.D. \\
\hline Participation & Active effort & 3.03 & .68 \\
\cline { 2 - 4 } & Student-faculty interaction & 2.36 & .77 \\
\cline { 2 - 4 } & Civic issues & 2.39 & .87 \\
\hline \multirow{3}{*}{ Attitudes } & Interest & 3.09 & .68 \\
\cline { 2 - 4 } & Motivation & 3.32 & .87 \\
\cline { 2 - 4 } & Concentration & 3.34 & .54 \\
\hline Approaches & Analysis & 3.21 & .90 \\
\hline \multirow{5}{*}{} & Integration & 3.27 & .88 \\
\cline { 2 - 4 } & Judgment & 3.13 & .89 \\
\cline { 2 - 4 } & Application & 3.13 & .98 \\
\hline
\end{tabular}

Note. Means represent the data transform from 1-5 point scale.

TABLE IV Descriptive Statistics for Learning Development

\begin{tabular}{|c|c|c|c|c|c|}
\hline Dimensions & Factors & Responses & Percent & Mean & S.D. \\
\hline \multirow{6}{*}{$\begin{array}{l}\text { Academic } \\
\text { performance }\end{array}$} & \multirow{6}{*}{$\begin{array}{l}\text { GPA } \\
\text { (score) }\end{array}$} & low & 2.8 & \multirow{6}{*}{3.22} & \multirow{6}{*}{.93} \\
\hline & & middle-low & 15.6 & & \\
\hline & & middle & 35.6 & & \\
\hline & & middle-high & 31.8 & & \\
\hline & & high & 4.0 & & \\
\hline & & missing values & 10.2 & & \\
\hline \multirow{6}{*}{$\begin{array}{l}\text { Learning } \\
\text { satisfaction }\end{array}$} & \multirow{6}{*}{$\begin{array}{c}\text { Satisfaction } \\
\text { of learning } \\
\text { activities }\end{array}$} & low & 24.8 & \multirow{6}{*}{2.99} & \multirow{6}{*}{1.52} \\
\hline & & middle-low & 11.2 & & \\
\hline & & middle & 13.1 & & \\
\hline & & middle-high & 22.5 & & \\
\hline & & high & 18.8 & & \\
\hline & & missing values & 9.6 & & \\
\hline \multirow{6}{*}{$\begin{array}{c}\text { Career } \\
\text { development }\end{array}$} & \multirow{5}{*}{$\begin{array}{c}\text { Career } \\
\text { ambition }\end{array}$} & low & 22.4 & 2.80 & 1.29 \\
\hline & & middle-low & 18.2 & & \\
\hline & & middle & 25.0 & & \\
\hline & & middle-high & 24.7 & & \\
\hline & & high & 9.2 & & \\
\hline & & missing values & .5 & & \\
\hline
\end{tabular}

Note. GPA represents low $=$ under 60 points, middle-low $=61-70$ points, middle $=71-80$ points, middle-high $=81-90$ points, high $=$ above 91 points".

The descriptive statistics of student engagement shows that participation is weighted in mediocre level; attitudes and approaches are similarly weighted in middle level, see Table III. The mean of student active effort is 3.03. While the student-faculty interaction and civic issues are 2.36 and 2.39 respectively. In the attitudes dimension, the means of interest, motivation, and concentration are 3.09, 3.32, and 3.34. Furthermore, the mean of cognitive approaches (analysis) is 3.21 , integration is 3.27 , judgment is 3.13 , and application also is 3.13 , see Table III.

The result reveals there are about $36 \%$ of students expressed below average level in their learning development. Specifically, there are $54 \%$ of students reported their academic 
performance left behind; approximately $50 \%$ of students reported they are unsatisfied with learning activities. Besides, there are $40.6 \%$ of students expressed their career ambition was in middle-low or low level, see Table IV.

\section{Differences between Student Engagement and Learning Development}

The result reveals that main differences of student engagement significantly derived from students' grade and location of universities. Senior students have significant student engagement, which can be explained by the factors of active effort $($ Mean $=3.16$, S.D. $=.70, \mathrm{~F}$-value $=6.560, p$ $<.001$ ), student-faculty interaction (Mean $=2.48$, S.D. $=.77$, F-value $=9.732, p<.001)$, civic issues $($ Mean $=2.52$, S.D. $=.89$, F-value $=5.153, p<.01)$, motivation $($ Mean $=3.45$, S.D. $=.91$, F-value $=3.725, p<.05)$, concentration $($ Mean $=$ 3.46, S.D. $=.58$, F-value $=9.341, p<.001$ ), and cognitive approaches $($ Mean $=3.30$, S.D. $=.74, \mathrm{~F}$-value $=9.836, p$ $<.001)$ respectively. In addition, college students in the central of Taiwan have shown better student engagement than do those in northern and southern areas. These differences also can be explained by the factors of active effort $($ Mean $=3.19$,
S.D. $=.63$, F-value $=14.262, p<.001)$, student-faculty interaction $($ Mean $=2.45$, S.D. $=.71$, F-value $=25.797, p$ $<.001)$, and motivation $($ Mean $=3.40$, S.D. $=.80$, F-value $=$ $4.466, p<.05)$ respectively.

On the other hand, the main differences of learning development are derived from students' major and sector to attend (public/private universities). Students majored in humanities and social sciences have better learning development than those majored in technology, which can be explained by the factors of academic performance (Mean = 3.38$, S.D. $=.90, t$-value $=9.472, p<.001)$, learning satisfaction $($ Mean $=3.39$, S.D. $=.79, t$-value $=5.974, p$ $<.001)$, and career development $($ Mean $=3.39$, S.D. $=.79, t$ value $=5.974, p<.001)$. Students in public universities have better learning development than those in private, which can be explained by the factors of academic performance (Mean = 3.40, S.D. $=.88, t$-value $=10.906, p<.001$ ), learning satisfaction $($ Mean $=3.33$, S.D. $=.80, t$-value $=1.984, p$ $<.05)$, and career development $($ Mean $=2.54$, S.D. $=.84, t$ value $=2.380, p<.05$ ).

TABLE V Difference of Student Engagement by SES

\begin{tabular}{|c|c|c|c|c|c|}
\hline Dimensions & Factors & Responses & Mean & F-value & Post Hoc test \\
\hline \multirow{20}{*}{ Participation } & \multirow{4}{*}{ writing } & low & 2.24 & \multirow{4}{*}{$5.300^{* * *}$} & \multirow{4}{*}{ High $<$ middle-low } \\
\hline & & middle-low & 2.33 & & \\
\hline & & middle-high & 2.19 & & \\
\hline & & high & 2.13 & & \\
\hline & \multirow{4}{*}{ reading } & low & 2.72 & \multirow{4}{*}{$8.547 * * *$} & \multirow{4}{*}{$\begin{array}{c}\text { Low }<\text { middle-low; } \\
\text { middle-high and high }< \\
\text { middle-low }\end{array}$} \\
\hline & & middle-low & 2.92 & & \\
\hline & & middle-high & 2.74 & & \\
\hline & & high & 2.70 & & \\
\hline & \multirow{4}{*}{ active effort } & low & 2.98 & \multirow{4}{*}{$4.236^{* *}$} & \multirow{4}{*}{ Low $<$ middle-low } \\
\hline & & middle-low & 3.11 & & \\
\hline & & middle-high & 3.04 & & \\
\hline & & high & 3.04 & & \\
\hline & \multirow{4}{*}{ student-faculty interaction } & low & 2.34 & \multirow{4}{*}{3.094} & \\
\hline & & middle-low & 2.45 & & \\
\hline & & middle-high & 2.39 & & \\
\hline & & high & 2.32 & & \\
\hline & \multirow{4}{*}{ civic issues } & low & 2.38 & \multirow{4}{*}{$4.309 * *$} & \multirow{4}{*}{ High $<$ middle-low } \\
\hline & & middle-low & 2.49 & & \\
\hline & & middle-high & 2.40 & & \\
\hline & & high & 2.28 & & \\
\hline \multirow{12}{*}{ Attitudes } & \multirow{4}{*}{ interest } & low & 3.07 & \multirow{4}{*}{.665} & \\
\hline & & middle-low & 3.09 & & \\
\hline & & middle-high & 3.12 & & \\
\hline & & high & 3.12 & & \\
\hline & \multirow{4}{*}{ motivation } & low & 3.29 & \multirow{4}{*}{2.232} & \\
\hline & & middle-low & 3.40 & & \\
\hline & & middle-high & 3.33 & & \\
\hline & & high & 3.30 & & \\
\hline & \multirow{4}{*}{ concentration } & low & 3.32 & \multirow{4}{*}{$4.642 * *$} & \multirow{4}{*}{$\begin{array}{l}\text { Low }<\text { middle-low; } \\
\text { middle-high }<\text { middle-low }\end{array}$} \\
\hline & & middle-low & 3.41 & & \\
\hline & & middle-high & 3.30 & & \\
\hline & & high & 3.35 & & \\
\hline \multirow{4}{*}{ Approaches } & \multirow{4}{*}{ cognitive approaches } & low & 3.17 & \multirow{4}{*}{$4.560 * *$} & \multirow{4}{*}{$\begin{aligned} \text { Low } & <\text { middle-low; high } \\
& <\text { middle-low }\end{aligned}$} \\
\hline & & middle-low & 3.29 & & \\
\hline & & middle-high & 3.17 & & \\
\hline & & high & 3.12 & & \\
\hline
\end{tabular}

Note. Values are indicated in ${ }^{*} p<<.01 . * * * p<.001(\mathrm{~N}=2,651)$. 


\section{Student Engagement and Learning Development Explained by SES}

This study has considered the impact of students with different social economic status (SES) on their engagement and learning development. We classified the students into four groups for comparing which are low, low-middle, high-middle, and high. The result reveals that students with low-middle SES exert better student engagement, which can be explained by the factors of active effort $($ Mean $=3.11$, S.D. $=.73$, F-value $=$ $4.236, p<.01$ ), civic issues (Mean $=2.49$, S.D. $=.94$, F-value $=4.309, p<.01)$, concentration $($ Mean $=3.41$, S.D. $=.56$, Fvalue $=4.642, p<.01$ ), and cognitive approaches (Mean $=$ 3.29, S.D. $=.79$, F-value $=4.560, p<.001)$, see Table V.

Meanwhile, the result also demonstrates that students with low-middle SES have better learning development, which can be explained by the factors of academic performance $($ Mean $=3.32$, S.D. $=.98, \mathrm{~F}$-value $=3.877, p<.01)$, and career development $($ Mean $=2.62$, S.D. $=.84$, F-value $=$ $6.450, p<.001)$, see Table VI.

TABLE VI Difference of Learning Development by SES

\begin{tabular}{|c|c|c|c|c|c|}
\hline Dimensions & Factors & Responses & Mean & F-value & $\begin{array}{c}\text { Post Hoc } \\
\text { test }\end{array}$ \\
\hline \multirow{4}{*}{$\begin{array}{c}\text { Academic } \\
\text { performance }\end{array}$} & \multirow{4}{*}{ GPA (score) } & low & 3.16 & \multirow{4}{*}{$3.877^{* * *}$} & \multirow{4}{*}{$\begin{array}{c}\text { Low }< \\
\text { middle- } \\
\text { low }\end{array}$} \\
\hline & & middle-low & 3.32 & & \\
\hline & & middle-high & 3.19 & & \\
\hline & & high & 3.22 & & \\
\hline \multirow{4}{*}{$\begin{array}{l}\text { Learning } \\
\text { satisfaction }\end{array}$} & \multirow{4}{*}{$\begin{array}{l}\text { Satisfaction } \\
\text { of learning } \\
\text { activities }\end{array}$} & low & 3.26 & \multirow{4}{*}{1.662} & \\
\hline & & middle-low & 3.34 & & \\
\hline & & middle-high & 3.33 & & \\
\hline & & high & 3.34 & & \\
\hline \multirow{4}{*}{$\begin{array}{c}\text { Career } \\
\text { development }\end{array}$} & \multirow{4}{*}{$\begin{array}{l}\text { Career } \\
\text { ambition }\end{array}$} & low & 2.50 & \multirow{4}{*}{$6.450^{* * * *}$} & \multirow{4}{*}{$\begin{array}{c}\text { High }< \\
\text { middle- } \\
\text { low }\end{array}$} \\
\hline & & middle-low & 2.62 & & \\
\hline & & middle-high & 2.52 & & \\
\hline & & high & 2.38 & & \\
\hline
\end{tabular}

Note. Values are indicated in $* * p<.01 ; * * * p .001 ; \mathrm{N}=2,651$.

\section{Conclusions}

This study demonstrates that the student engagement survey can be used to determine how well college students learn, what to learn, and why to learn. What level of the undergraduate students' engagement reflected not only the quality of higher education but the learning effectiveness. The results reveal that both student engagement and learning development are in unsatisfied level; their participations are moderate; attitudes and approaches are in middle level, and students' learning development is below average level. The findings might reflect the core issue of the over expanded higher education system.

Theoretically, we support that enhancing student engagement could prompt to students' critical thinking, problem solving, effective communication, and responsible citizenship. Therefore, higher education institutions need well organized curriculum and meaningful campus activities for enriching their students' learning experiences. Specifically, this study demonstrates both low and high SES groups are inferior in their engagement and learning development in this system. We suggest reconsidering the SES issue to ameliorate this phenomenon directly in campus.

\section{Acknowledgement}

This work was supported by the Ministry of Science and Technology, Taiwan under the grants for developing institutional academic affairs.

\section{References}

[1] Ministry of Education, "Summary of tertiary education institutes (19922012)," Retrieved

from https://stats.moe.gov.tw/files/main_statistics/u.xls, 2013.

[2] Ministry of Education, "Summary of education at all levels in SY 2011," Retrieved from http://english.moe.gov.tw/ct.asp?xItem $=14487 \& c t$ Node $=11429 \& m p=1$, 2013.

[3] W. Astin, What Matters in College? Four Critical Years Revisited, San Francisco, CA: Jossey-Bass, 1993.

[4] G. D. Kuh, "Assessing what really matters to student learning: Inside the National Survey of Student Engagement," Change, vol. 33, no. 3, pp. 1017, 66, 2001.

[5] C. R. Pace, "Measuring the quality of student effort," Current Issues in Higher Education, vol. 2, pp. 10-16, 1980.

[6] T. Pascarella and P. T. Terenzini, How College Affects Students: Findings and Insights from Twenty Years of Research, San Francisco, CA: Jossey-Bass, 1991.

[7] W. Chickering and Z .F. Gamson, "Seven principles for good practice in undergraduate education," AAHE Bulletin, vol. 39, no. 7, pp. 3-7, 1987.

[8] J. Brophy, Motivating Students to Learn (2nd ed.), Mahwah, NJ: Lawrence Erlbaum, 2004.

[9] K. R. Wentzel, "Social relationships and motivation in middle school: The role of parents, teachers, and peers," Journal of Educational Psychology, vol. 90, pp. 202-209, 1998.

[10]J. A. Fredericks, P. C. Blumenfeld, and A. H. Paris, "School engagement: Potential of the concept, state of the evidence," Review of Educational Research, vol. 74, pp. 59-109, 2004.

[11]M. J. Furlong and S. L. Christenson, "Engaging students at school and with learning: A relevant construct for all students," Psychology in the Schools, vol. 45, no. 5, pp. 365-368, 2008.

[12]Chapman, "Alternative approaches to assessing student engagement rates," Practical Assessment, Research and Evaluation, vol. 13, no. 8, pp. 1-7, 2003.

[13]L. H. Bass and A. S. Ballard, "Student engagement and course registration methods as possible predictors of freshman retention," Research in Higher Education Journal, vol. 19, pp. 1-15, 2012.

[14]NSSE, "Finances affect student academically, NSSE 2012 finds," Retrieved

http://www.insidehighered.com/news/2012/11/15/finances-affectstudents-academically-nsse-2012-finds\#sthash.4ufuHkHU.dpbs, 2012. 